\title{
Dolomite in caves: Recent dolomite formation in oxic, non-sulfate environments. Castañar Cave, Spain
}

\author{
Ana M. Alonso-Zarza *, Andrea Martín-Pérez \\ Dpto. de Petrología y Geoquímica, Fac. CC. Geológicas-Instituto de Geología Económica, Universidad Complutense-CSIC, 28040 Madrid, Spain
}

\section{A R T I C L E I N F O}

\section{Article history:}

Received 9 August 2007

Received in revised form

26 February 2008

Accepted 29 February 2008

Keywords:
Dolomite
Caves
Huntite
Low-temperature
Recent
Castañar Cave
Spain

\begin{abstract}
A B S T R A C T
Dolomite is a common mineral in the rock record but rare in recent superficial environments. Where it does occur, it is related to anoxic, sulfate-rich environments and microbial activity. The occurrence of some dolomite deposits in caves, however, indicates that dolomite formation is also possible in oxic, non-sulfate settings. Dolomite is forming at $17{ }^{\circ} \mathrm{C}$ and in oxic-vadose conditions on the host rocks and aragonite speleothems of the Castañar Cave, Cáceres, Spain. It appears as spheroids and dumbbells 50-300 $\mu \mathrm{m}$ in diameter that internally consist of micron-sized rhombic to rounded crystals. Initially this dolomite is Carich, non-stoichiometric and poorly ordered. Mg-rich solutions allow the precipitation of metastable Mg-rich carbonates, such as huntite. This soon transforms into this Ca-rich dolomite, which later "ages" to form a more stoichiometric dolomite. These dolomites show similarities to those grown under anoxic, sulfate-rich conditions and their presence in caves provides a different setting that may contribute to the understanding of the "dolomite problem", including their initial formation and later recrystallization processes.
\end{abstract}

\section{Introduction}

Dolomite is common in ancient marine and continental rocks, but is very rarely found in recent, sedimentary, low temperature environments. Its formation in the laboratory at low temperatures is almost impossible without bacterial mediation (Land, 1998; Burns et al., 2000). Most recently formed dolomite is associated with marine settings under the influence of sulfate-reducing bacteria and mostly anoxic conditions (Vasconcelos and McKenzie, 1997). In peritidal beachrocks, bacteria also play a role in dolomitization due to methane oxidation in presence of $\mathrm{SO}_{4}^{-2}$, which provided $\mathrm{HCO}_{3}^{-}$for dolomite formation (Friedman, 1991). Old dolomites have been described in ancient caves (Nielsen et al., 1997). Little is known, however, about dolomites that form in oxic, sulfate-poor settings, such as recent caves (Thrailkill, 1968). Such dolomites, as those of the Castañar Cave, may provide information that will help resolve the “dolomite problem" (Land, 1998; Arvidson and Mackenzie, 1999) either through direct precipitation from the cave waters or by transformations from metastable minerals, such as aragonite or huntite. Moreover it will be also possible to study the ageing or recrystallization processes of these poorly ordered dolomites.

\section{Geological setting and mineral associations in the cave}

Castañar Cave is situated in Cáceres, Spain. It is hosted in Neoproterozoic rocks that form the core of the Ibor Anticline (Fig. 1). These

\footnotetext{
* Corresponding author.

E-mail address: alonsoza@geo.ucm.es (A.M. Alonso-Zarza).
}

rocks are shales and greywackes with interbedded dolostones and magnesites (Alonso Zarza et al., 2005a). Dissolution of the dolomitic beds and the extensive weathering of the shales and greywackes favor collapses which create and enlarge the cavities. This dissolution also determines the composition of the cave waters, which are rich in $\mathrm{Mg}$. The waters show $\mathrm{Ca} / \mathrm{Mg}$ ratios of $0.5->1.0$ and are usually saturated in calcite, dolomite and aragonite (Sánchez-Moral et al., 2006). The mean temperature of the cave is $17^{\circ} \mathrm{C}$ (very constant year round); the relative humidity of the air is close to $100 \%$ (Sánchez-Moral et al., 2006).

In the Castañar Cave, in Cáceres, Spain, dolomite occurs as a minor component of speleothems. Mineral precipitation in the cave follows the classic sequence. In this sequence as a result of the precipitation of calcite and aragonite, drip waters become relatively enriched in $\mathrm{Mg}$, favoring the precipitation of hydromagnesite (Self and Hill, 2003). In Castañar, huntite globules or rosettes composed of platelets are commonly formed instead of hydromagnesite (Alonso Zarza et al., 2005b). Dolomite is common in moonmilk deposits together with huntite when drip water dries.

\section{Methods and materials}

The mineralogy of 33 samples from the Castañar Cave was studied using a Philips PW-1710 XRD system operating at $40 \mathrm{kV}$ and $30 \mathrm{~mA}$ and with monochromated $\mathrm{CuK} \alpha$ radiation. XRD spectra were obtained from 2 to $66^{\circ} 2 \theta$. The degree of ordering of the samples was determined from diffraction patterns obtained at a velocity of $0.5^{\circ} / \mathrm{min}$ over the range $31-39^{\circ} 2 \theta$. In order to check if composition and relative degree of order show some correlation, the ratio between the intensity of d015 


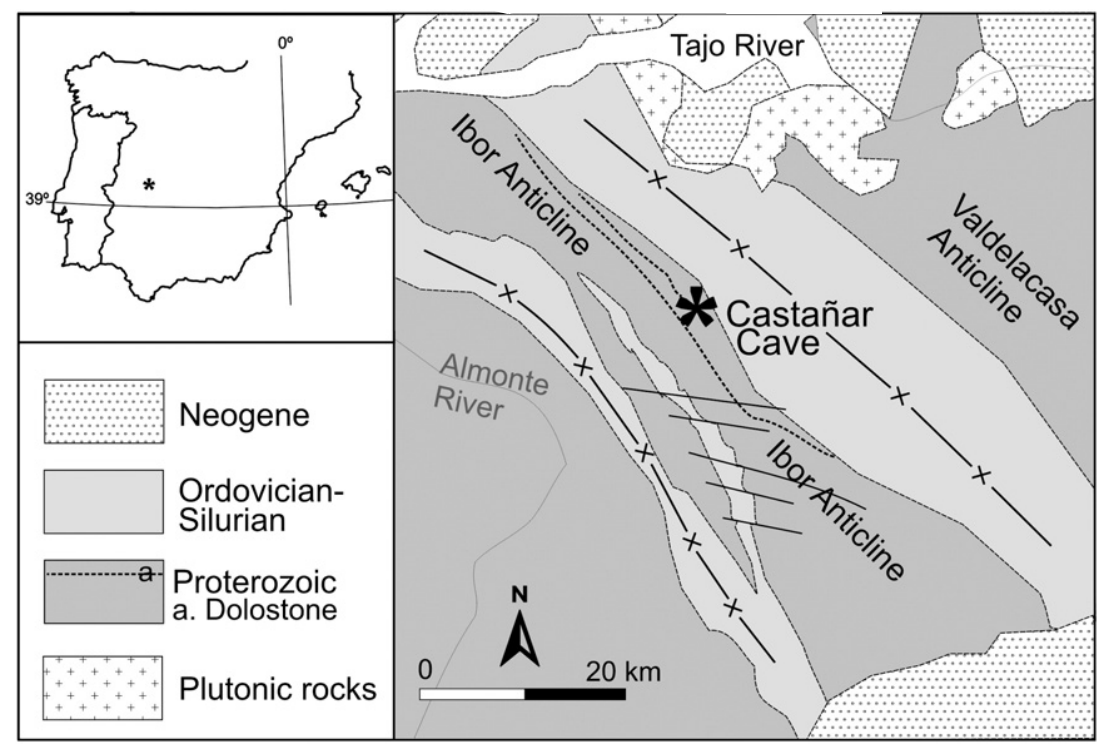

Fig. 1. Location of the Castañar Cave within the Iberian Península. Simplified geological map of the studied area.

(superstructure peak) and d110, was measured according to standard procedures (Hardy and Tucker, 1988). Sixty nine samples were subjected to conventional optical petrographic analysis. Due to the fragility of the samples these were previously submerged in a resin containing Epofer EX 401 and Epofer E 432 in a vacuum system. In all cases the obtained thin sections were polished on both sides to favor their study with an electronic microprobe. Scanning electron microscopy was performed on 43 gold-coated samples. Observations were made using a JEOL 6400 working at $20 \mathrm{kV}$ and with a resolution of $35 \AA$; secondary electron and backscattering detectors (BSE) were used together with an X-ray detection system (XDS) to obtain semiquantitative compositions. $\mathrm{Mg} / \mathrm{Ca}$ ratios of the dolomites were obtained using an electronic microprobe (JEOL JXA $8900 \mathrm{M}$ ) operating at $15 \mathrm{Kv}$ and $20 \mathrm{nA}$ and with an electron beam of $5 \mu$ diameter.

\section{Dolomite features in the Castañar Cave}

Macroscopically, the dolomite in the Castañar Cave occurs as an opaque white to orange precipitate (Fig. 2). This dolomite is found: 1) as scattered spheroids on the host rock shales; 2 ) growing on fibrous aragonite crystals (Fig. 3A and B) which it etches, corrodes and may completely replace; 3 ) nucleating on huntite $\mathrm{CaMg}_{3}\left(\mathrm{CO}_{3}\right)_{4}$ globules to form spheroids of dolomite that include relics of huntite and sepiolite; and 4) replacing huntite globules and fibrous aragonite crystals on which huntite had previously formed.

The dolomite in the cave is found as dumbbells (Fig. 3C) or spheroids (Fig. 3D) 50-300 $\mu \mathrm{m}$ across. The dumbbells are composite crystals that consist of fibrousradial aggregates that internally are formed by individual rhombic dolomite crystals $(1 \mu \mathrm{m}$ wide). The spheroids represent an advanced stage of growth of these dumbbells, in which the crystals are aligned along all the axes of the sphere to produce a radial, fibrous structure. Similar development has been recorded in the experimental growth of Ca-Mg carbonates (Castanier et al., 1989; Rivadeneyra et al., 2006). The individual dolomite crystals vary in shape from rhombohedral to rounded. Both the dumbbells and spheroids can be found isolated or coalescing to form coatings on the growth surfaces (host rocks, aragonite or huntite). Huntite coats some aragonite crystals. It occurs as white and fine precipitated that form globules. The globules consist of platelet crystals, $\sim 1 \mu \mathrm{m}$ long. Relics of huntite platelets are commonly found in the dolomite dumbbells and spheroids.

In some cases, dolomite totally replaces the aragonite or huntite to form a coarse mosaic of dolomite crystals (Fig. 3E). Dolomite mosaics are formed by rounded to euhedral crystals about $0.2 \mathrm{~mm}$ across; relics of huntite and aragonite are in cases preserved within them (Fig. 3F). Some of these mosaics serve as nucleation sites for new aragonite fans and huntite, although they can also be used as nuclei for the growth of further dolomite with no inclusions and no precursors.

The dolomite in this cave is poorly ordered. The degree of order varies from 0 (without superstructure peak d015) to 0.86 . Fig. 4 shows the high degree of order of the host-rock dolomite and the variation of order of different samples from the cave dolomite. Analyses performed on individual crystals indicate Ca-rich dolomite in most of the cases. The values vary between $62.5 \%$ to $50 \% \mathrm{~mol} \mathrm{CaCO}_{3}$, with a mean value of $56.5 \% \mathrm{~mol} \mathrm{CaCO}_{3}$ (mean $\mathrm{Mg} / \mathrm{Ca}$ ratio 0.77 ), which defines high-Ca calcian dolomites (Jones and Luth, 2002). Experiments on Ca-Mg carbonate formation at low temperatures (Fritz and Smith, 1970) have shown the dolomite produced to be disordered, and the $\mathrm{Mg} / \mathrm{Ca}$ ratio to be around 0.6-0.7. Superstructure peaks were also lacking in the dolomite formed in these experiments; the authors considered this phase to be a precursor mineral for dolomite formation.

In the coarse dolomite mosaics in the Castañar Cave, the degree of ordering is higher and the mineral approaches stoichiometric composition. The Ca-richer dolomites show less ordering. Microprobe images in backscatter mode show the different composition of the dolomites from the closest areas to the aragonite fibers to the outer part. The dolomite that surrounds the aragonite is lighter indicating

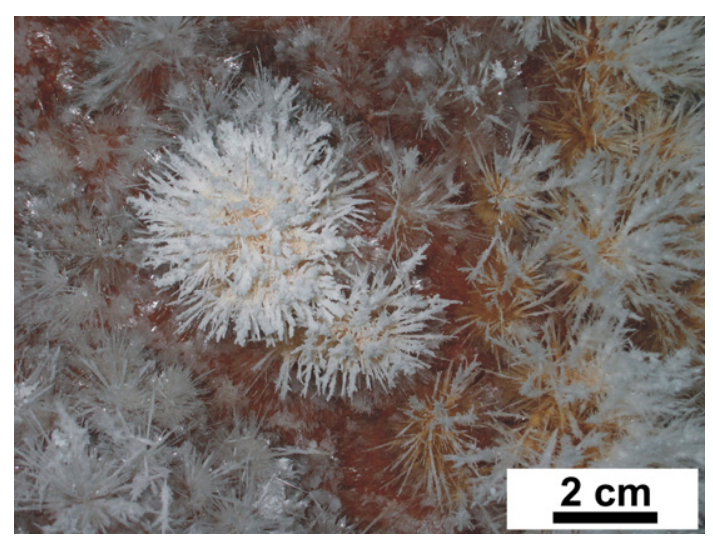

Fig. 2. Radially aligned aragonite crystals growing on the walls of the cave. The aragonite shows a thin, opaque coating of white dolomite thickening the individual aragonite needles. 

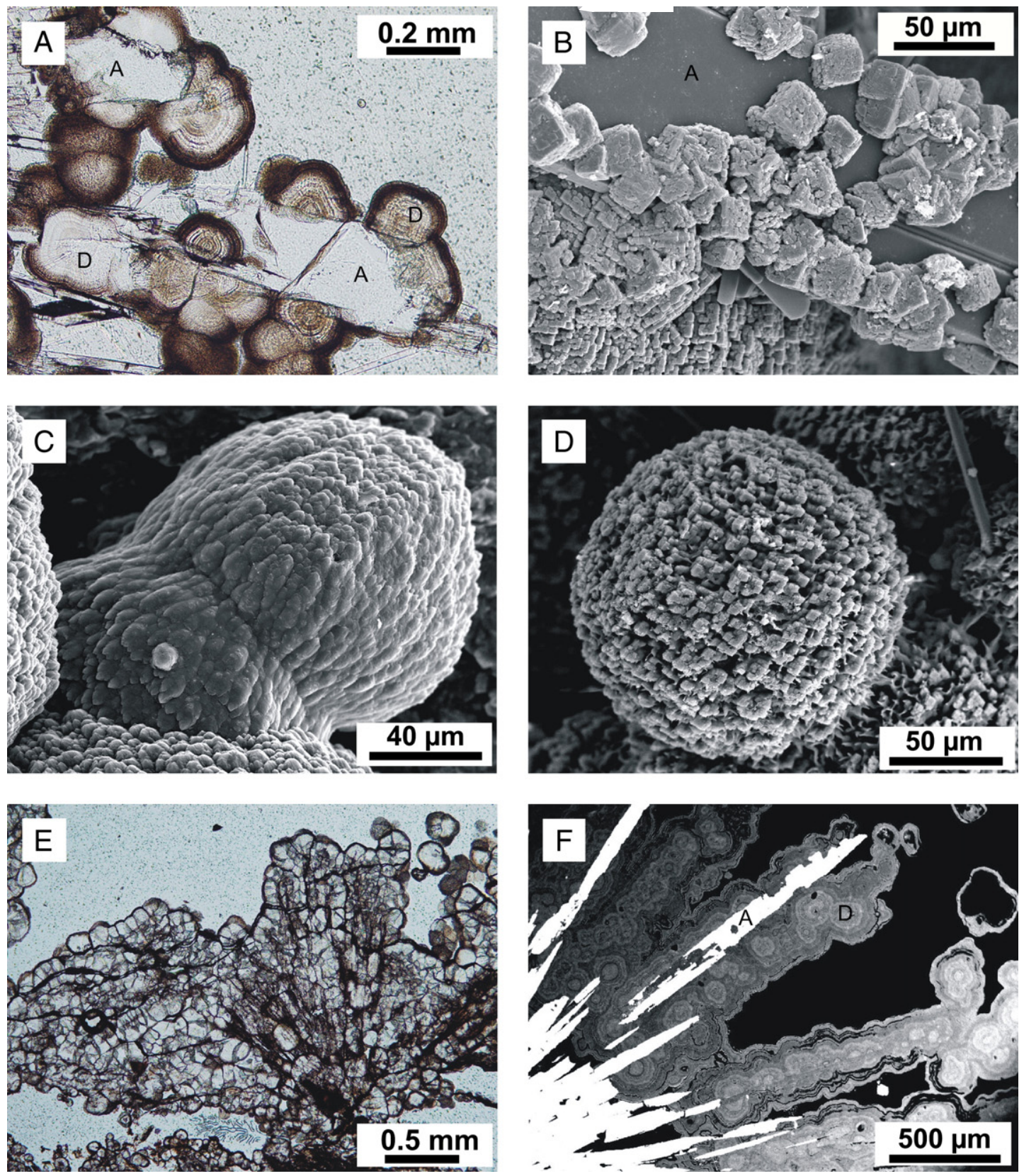

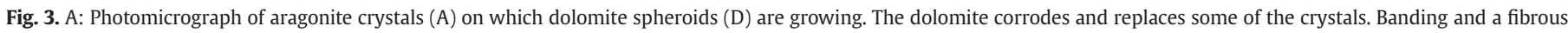

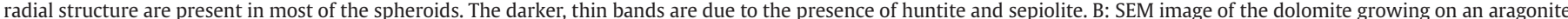

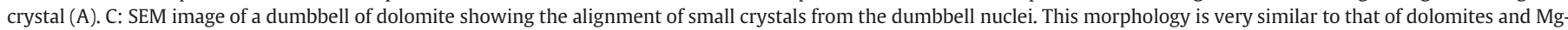

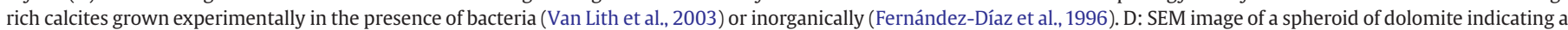

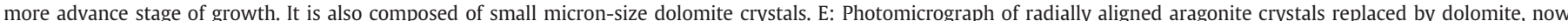

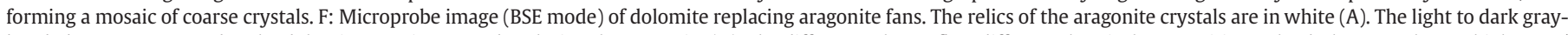

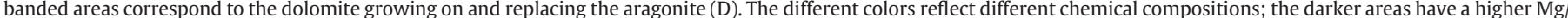

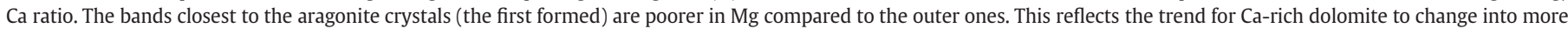
stoichiometric dolomite over time.

higher Ca content whereas the outermost and darker areas are closer to the stoichiometric composition of dolomite (Fig. 3F).

\section{Discussion}

In the Castañar Cave, $\mathrm{Mg}$-Ca carbonates are forming as the final products of precipitation from water that becomes relatively enriched with respect to $\mathrm{Mg}$ due to the initial precipitation of aragonite and calcite. In Mg-rich solutions such as those found in this cave (SánchezMoral et al., 2006), the precipitation of aragonite is favored, whereas calcite growth is kinetically and thermodynamically inhibited due to the poisoning effect of partially dehydrated $\mathrm{Mg}$ (Berner, 1975). The latter attaches to the surfaces of incipient calcite nuclei, inhibiting their growth and favoring the formation of aragonite (Lippmann, 1973; Raz et al., 2000), which contains no Mg. Thus, the solution becomes relatively enriched in $\mathrm{Mg}$, and can become saturated in $\mathrm{Ca}-\mathrm{Mg}$ phases such as magnesite, huntite (Deelman, 2003) or hydromagnesite in addition to dolomite (Sánchez-Moral et al., 2006). Huntite can form at low temperature surface or near-surface conditions; either by direct precipitation from $\mathrm{Mg}$-rich solutions or by interaction of the $\mathrm{Mg}$-rich water with precursor carbonate minerals (Dollase and Reeder, 1986). It is commonly recognized in moonmilk deposits in caves (together with 


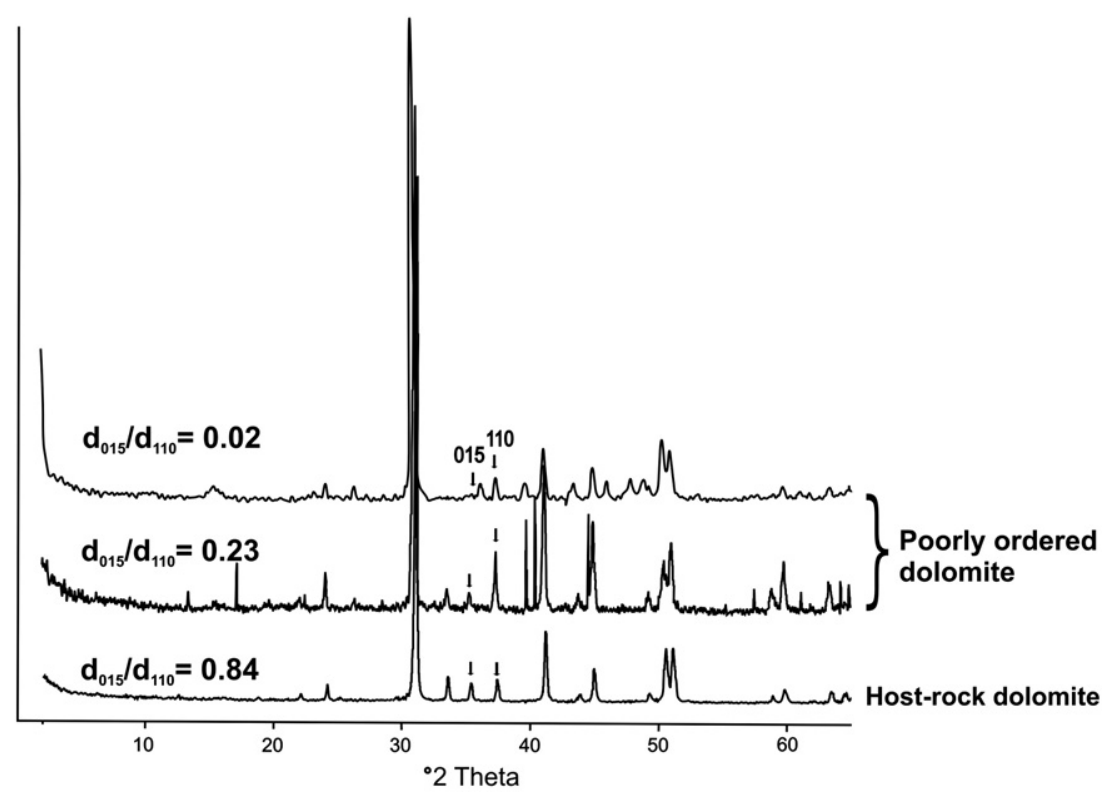

Fig. 4. XRD patterns of samples of cave dolomites with different degree of order and comparision to that of a dolomite from the host rock.

magnesite and dolomite) (Polyak and Güven, 2000), in which the sequence of mineral precipitation due to the progressive increase in the $\mathrm{Mg} / \mathrm{Ca}$ ratio and $\mathrm{CO}_{2}$ loss is: calcite, aragonite, dolomite, huntite and magnesite (Casas et al., 2001). This sequence, however, does not take into account the possible transformation of metastable minerals into more stable forms. Experimental studies (Davies et al.,1977) have shown that huntite always precipitates before dolomite, the main factor controlling the formation of both being the increase/maintenance of the $\mathrm{CO}_{3}^{2-}$ concentration. Huntite grows before dolomite since its more open structure allows Mg dehydration more readily (Lippmann, 1973). The necessary increase/maintenance of $\mathrm{CO}_{3}^{2-}$ can be obtained either by dissolution of previous hydrous Mg carbonates (Kinsman, 1967) or by photosynthetic activity (Davies et al., 1977), although in the cave the latter is impossible due to the lack of light.

The possibility that huntite might be a precursor of dolomite has been proposed (Lippmann, 1973), but this transformation has rarely been taken into account, even when considering solutions to the "dolomite problem". After 31 years of continued experiments, dolomite has never been found to form inorganically at $25^{\circ} \mathrm{C}$ (Land, 1998). There is agreement that dolomite formation is rare under environmental conditions due to thermodynamic constraints (Machel and Mountjoy, 1986). However, some catalysts (Land, 1998) might allow for the easy low temperature laboratory synthesis of dolomite. In recent years it has been shown that, in anaerobic environments, sulfate-reducing bacteria can induce the low temperature formation of Ca-rich dolomite and $\mathrm{Mg}$ rich calcite, both in natural environments and under experimental conditions (Vasconcelos and McKenzie, 1997; Van Lith et al., 2003). Bacteria play a passive role in this dolomite formation; precipitation is induced simply because of the modification of the microenvironment around the bacterial cells (Vasconcelos et al., 2005). Huntite itself (Lippmann, 1973) or hydrous calcium magnesium carbonates (Kelleher and Redfern, 2002; Schmidt et al., 2005) may also act as catalysts or precursors, as shown by the experimental synthesis of dolomite in the absence of microorganisms.

In Castañar Cave, the common association of huntite and dolomite and the presence of huntite relics in some of the dolomite mosaics, strongly indicate that dolomite is formed by the transformation or replacement of huntite. At present no clear conclusions can be drawn on possible organic influences for two reasons: i) laboratory-produced organic (Castanier et al., 1989; González-Muñoz et al., 2000; Van Lith et al., 2003) and inorganic (Fernández-Díaz et al., 1996) crystalline habits and morphological sequences are the same as those seen in the dolomites in the Castañar Cave, and ii) organic morphologies (such as fungal filaments or spheres of possible bacteria) are very rare and were found only on the surface of the dolomites (never inside), suggesting that either the organic structures are lost once the crystals are formed, or that they do not play a role in the formation of dolomite. In any event, candidate microbes ought not be light-dependant since the cave is a dark (as well as oxic and sulfate-poor) environment. Further studies are needed to determine the influence of microbes in the formation of this dolomite.

In the Castañar Cave, the dolomite-type mineral that initially forms is Ca-rich and lack, in some cases, of superstructure peaks. However, the ageing and/or recrystallization of this dolomite to more stoichiometric and ordered one occurs, as shown by the eventual appearance of superstructure peaks, the variation of the degree of order and the lower $\mathrm{Ca} / \mathrm{Mg}$ ratios. This recrystallization process has been described in Holocene peritidal dolomites (Gregg et al., 1992). This is driven by the Ostwald ripening process (Ostwald, 1900), in which surface recrystallization is due to the growth of large crystals at the expense of smaller ones. There is no change of volume but the number of crystals per unit volume decreases. Equilibrium is reached with the formation of a final single crystal or when all the crystals are of the same size, which in the Castañar Cave occurs in the mosaics formed by the largest dolomite crystals. Texturally this transformation is seen as a loss of the radial fibrous structure (of both the dumbbells and spheroids), to form single crystals with an undulate to straight extinction pattern, which are more ordered dolomites.

\section{Conclusions}

Dolomite formation in Castañar Cave was favored because the cave forms by dissolution of dolomites and magnesites. Prior precipitation of calcite and aragonite favors the enrichment of the vadose waters with $\mathrm{Mg}$, in which huntite precipitates before dolomite because of its more open structure. However it transforms to poorly ordered Ca-rich dolomite that later ages to more ordered dolomite, forming coarse crystalline mosaics. The initial dolomite shows dumbell and spheroid morphologies similar to natural dolomites formed in the presence of bacteria and to experimentally grown "organic" and "inorganic" dolomites.

Dolomite is a common mineral in ancient marine and terrestrial deposits. In recent sedimentary environments it is very rare; where it does occur it is often related to anoxic, sulfate-rich environments. It seems, however, to be present in small quantities in several vadose 
caves, where it forms in oxic, sulfate-poor environments and at low temperatures. Recently formed cave dolomites may be more abundant than presently believed, and further studies are needed to determine their exact mechanism of formation and to clarify the possible influence of microbes. Caves may be important, natural, low temperature environments for dolomite formation; such dolomite may provide new information that could help solve the "dolomite problem".

\section{Acknowledgments}

We thank the financial support from the Junta de Extremadura through FEOGA-ORIENTACION-FEDER funds and Project CGL200505953-C02-02. I. Gil, P. Muñoz-Barco, E. Martínez and A. Blázquez are thanked for discussion during the "cave work". V.P. Wright made interesting comments on an earlier version of the manuscript. A. Burton carefully reviewed the text style. A. Martín-Pérez was supported by an I3P-CSIC grant. The reviewers, G.M. Friedman and B. Jones, contributed greatly to improve the quality of the manuscript.

\section{References}

Alonso Zarza, A.M., Gil Peña, I., Martínez Flores, E., Muñoz Barco, P., 2005a. La cueva de Castañar. In: Muñoz Barco, P., Martínez Flores, E. (Eds.), Patrimonio Geológico de Extremadura: Geodiversidad y lugares de interés geológico. Junta de Extremadura, pp. 99-111.

Alonso Zarza, A.M., Martín Pérez, A., Gil Peña, I., Martínez Flores, E., Muñoz Barco, P., 2005b. Formación de dolomita y huntita en depósitos de tipo moon-milk en la cueva de Castañar de Ibor (Cáceres). Geogaceta 38, 247-250.

Arvidson, R.S., Mackenzie, F.T., 1999. The dolomite problem: control of precipitation kinetics by temperature and saturation state. American Journal of Science 299, 257-288.

Berner, R.A., 1975. The role of magnesium in the crystal growth of calcite and aragonite from sea water. Geochimica et Cosmochimica Acta 39 (4), 489-494.

Burns, S.J., McKenzie, J.A., Vasconcelos, C., 2000. Dolomite formation and biogeochemical cycles in the Phanerozoic. Sedimentology 47 (1), 49-61.

Casas, J., Martín de Vidales, J.L., Durán, J.J., López Martínez, J., Barea, J., 2001. Mineralogía de depósitos tipo moonmilk en la cueva de Nerja (Málaga, España). Geogaceta 29, 29-32.

Castanier, S., Maurin, A., Perthuisot, J.P., 1989. Production bactérienne expérimentale de corpuscules carbonatés, sphéroïdaux à structure fibro-radiaire. Réflexions sur la définition des ooïdes. Bulletin de la Société géologique de France 5 (3), 589-595.

Davies, P.J., Bubela, B., Ferguson, J., 1977. Simulation of carbonate diagenetic processes: formation of dolomite, huntite and monohydrocalcite by the reactions between nesquehonite and brine. Chemical Geology 19, 187-214.

Deelman, J.C., 2003. Low Temperature Formation of Dolomite and Magnesite. Geology Series. Compact Disc Publications, Eindhoven (The Netherlands). 504 pp.

Dollase, W.A., Reeder, R.J., 1986. Crystal structure refinement of huntite, $\mathrm{CaMg}_{3}\left(\mathrm{CO}_{3}\right)_{4}$, with X-ray powder data. American Mineralogist 71 (1-2), 163-166.

Fernández-Díaz, L., Putnis, A., Prieto, M., Putnis, C.V., 1996. The role of magnesium in the crystallization of calcite and aragonite in a porous medium. Journal of Sedimentary Research 66 (3), 482-491.
Friedman, G.M., 1991. Methane-generated lithified dolostone of Holocene age; eastern Mediterranean. Journal of Sedimentary Research 61 (2), 188-194.

Fritz, P., Smith, D.G.W., 1970. The isotopic composition of secondary dolomites Geochimica et Cosmochimica Acta 34 (11), 1161-1173.

González-Muñoz, M.T., Ben Chekroun, K., Ben Aboud, A., Arias, J.M., Rodriguez-Gallego, M., 2000. Bacterially induced $\mathrm{Mg}$-calcite formation: role of $\mathrm{Mg}^{2+}$ in development of crystal morphology. Journal of Sedimentary Research 70 (3), 559-564.

Gregg, J.M., Howard, S.A., Mazzullo, S.J., 1992. Early diagenetic recrystallization of Holocene ( $<3000$ years old) peritidal dolomites, Ambergris cay, Belize. Sedimentology $39,143-160$.

Hardy, R., Tucker, M., 1988. X-ray powder diffraction of sediments. In: Tucker, M.E. (Ed.) Techniques in Sedimentology. Blackwell Scientific Publications, Oxford, pp. 191-228.

Jones, B., Luth, R.W., 2002. Dolostones from Grand Cayman, British West Indies. Journal of Sedimentary Research 72 (4), 559-569.

Kelleher, I.J., Redfern, A.T., 2002. Hydrous calcium magnesium carbonate, a posssible precursor to the formation of sedimentary dolomite. Molecular Simulation 28, 557-572.

Kinsman, D.J.J., 1967. Huntite from a carbonate-evaporite environment. American Mineralogist 52, 1332-1340.

Land, L.S., 1998. Failure to precipitate dolomite at $25{ }^{\circ} \mathrm{C}$ from dilute solution despite 1000-fold oversaturation after 32 years. Aquatic Geochemistry 4 (3), 361-368.

Lippmann, F., 1973. Sedimentary Carbonate Minerals. Springer-Verlag, New York. 228 pp

Machel, H.G., Mountjoy, E.W., 1986. Chemistry and environments of dolomitization-a reappraisal. Earth-Science Reviews 23, 175-222.

Nielsen, P., Swennen, R., Dickson, J.A.D., Fallick, A.E., Keppens, E., 1997. Spheroidal dolomites in a Visean karst system-bacterial induced origin? Sedimentology 44(1), 177-195.

Ostwald, W., 1900. Über die vermeintliche Isomerie des rotten und gelben Quecksilberoxyds und die Oberflächenspannung fester Körper. Zeitschrift Fur Physikalische Chemie, vol. 34, pp. 495-503.

Polyak, V.J., Güven, N., 2000. Authigenesis of trioctahedral smectite in magnesium-rich carbonate speleothems in Carlsbad Cavern and other caves of the Guadalupe Mountains, New Mexico. Clays and Clay Minerals 48 (3), 317-321.

Raz, S., Weiner, S., Addadi, L., 2000. Formation of high-magnesian calcites via an amorphous precursor phase: possible biological implications. Advanced Materials $12(1), 38-42$.

Rivadeneyra, M.A. Martín-Algarra, A., Sánchez-Navas, A, Martín-Ramos, D, 2006. Carbonate and phosphate precipitation by Chromohalobacter marismortui. Geomicrobiology Journal 23 (2), 89-101.

Sánchez-Moral, S., Cuezva, S., Lario, J., Taborda-Duarte, M., 2006. Hydrochemistry of karstic waters in a low-energy cave (Castañar de Ibor, Spain). In: Durán, J.J., Andreo, B., Carrasco, F. (Eds.), Karst, cambio climático y aguas subterráneas. Hidrogeología y Aguas Subterráneas. IGME, Madrid, pp. 339-347.

Schmidt, M. Xeflide, S., Botz, R., Mann, S, 2005. Oxygen isotope fractionation during synthesis of CaMg-carbonate and implications for sedimentary dolomite formation. Geochimica et Cosmochimica Acta 69 (19), 4665-4674.

Self, C.A., Hill, C.A., 2003. How speleothems grow: an introduction to the ontogeny of cave minerals. Journal of Cave and Karst Studies 65 (2), 130-151.

Thrailkill, J.V., 1968. Dolomite cave deposits from Carlsbad Caverns. Journal of Sedimentary Petrology 38 (1), 141-145.

Van Lith, Y., Warthmann, R., Vasconcelos, C., Mckenzie, J.A., 2003. Sulphate-reducing bacteria induce low-temperature $\mathrm{Ca}$-dolomite and high $\mathrm{Mg}$-calcite formation. Geobiology 1 (1), 71-79.

Vasconcelos, C., McKenzie, J.A., 1997. Microbial mediation of modern dolomite precipitation and diagenesis under anoxic conditions (Lagoa Vermelha, Rio de Janeiro, Brazil). Journal of Sedimentary Research 67 (3), 378-390.

Vasconcelos, C., McKenzie, J.A., Warthmann, R., Bernasconi, S.M., 2005. Calibration of the $\delta^{18} \mathrm{O}$ paleothermometer for dolomite precipitated in microbial cultures and natural environments. Geology 33 (4), 317-320. 